\title{
Age, duration of work, noise and vibration in inducing hearing and balance impairments
}

\author{
Jenny Bashiruddin
}

\begin{abstract}
Abstrak
Bajaj, sebagai model pada penelitian ini, merupakan kendaraan angkutan dengan tingkat kebisingan yang cukup tinggi. Hal ini dapat menimbulkan gangguan pendengaran dan keseimbangan pada pengemudinya. Subjek dipilih secara konsekutif di antara pengemudi bajaj di Jakarta dan dilakukan pemeriksaan pendengaran dengan audiometer dan pemeriksaan keseimbangan dengan gravicorder di pagi hari di poliklinik Neurotologi Departemen Telinga Hidung dan Tenggorok RSUPN Cipto Mangunkusumo, Jakarta dari bulan Maret 2000 sampai Oktober 2001. Dari 350 subjek yang diperoleh, ditemukan 97 subjek tanpa gangguan pendengaran dan keseimbangan dan 96 subjek yang menderita gangguan pendengaran dan keseimbangan. Jika dibandingkan dengan pengemudi bajaj berumur kurang dari 40 tahun, pengemudi bajaj yang berumur 41 tahun atau lebih mempunyai risiko hampir 4 kali lipat untuk menderita gangguan pendengaran dan keseimbangan [rasio odds suaian $(O R)=3,90 ; 95 \%$ interval kepercayaan $(C I)=1,67-9,10$ ] . Pengemudi bajaj yang bekerja lebih dari 9 jam per hari mempunyai risiko 2,3 kali lipat untuk menderita gangguan pendengaran dan keseimbangan jika dibandingkan dengan pengemudi yang bekerja kurang dari 9 jam (OR suaian = 2,32; 95\% CI=1,22-4,41). Di samping itu, jika dibandingkan dengan mereka yang bekerja 1-5 tahun, mereka yang telah bekerja lebih dari 5 tahun mempunyai kecenderungan menderita gangguan pendengaran dan keseimbangan, dan di antara yang telah bekerja 21-30 tahun mempunyai risiko lebih dari 7 kali lipat $(O R$ suaian $=7,11 ; 95 \% C I=1,88-26,92)$. Untuk mengurangi risiko gangguan pendengaran dan keseimbangan, pengemudi bajaj dianjurkan bekerja kurang dari 8 jam per hari. (Med J Indones 2005; 14: 101-6)
\end{abstract}

\begin{abstract}
Noisy and vibrating bajaj, a public transportation in Jakarta, is a potential risk in inducing hearing and balance problems. Bajaj drivers in the Jakarta area were chosen by consecutive sampling and examined medically in the Neurotological Subdivision of the ENT Department of the Cipto Mangunkusumo Hospital, Jakarta. Hearing and balance impairments were then diagnosed from audiometric and posturographic tests. The study was carried out from March 2000 until October 2001. A number of 350 bajaj drivers participated in this study. There were 97 subjects without hearing and balance impairments, and 96 subjects suffered from hearing and balance impairments. Compared to drivers aged less than 40 years, those aged 41 years or more had a four-fold increased risk of developing hearing and balance impairments [adjusted odds ratio $($ OR $)=3.90 ; 95 \%$ confidence interval $(C I)=1.67-9.10$ ]. Drivers working 9 hours or more a day had an increased risk 2.3 times of developing hearing and balance impairments compared those working less than 9 hours a day (adjusted $O R=2.32 ; 95 \% C I=1.22-4.41$ ). Furthermore, when compared to those who had been working for 1-5 years, those who had been working for 5 years had an increased tendency of developing hearing and balance impairments. Those who had been working 21-30 years had a seven-fold increased risk of developing hearing and balance impairments (adjusted $O R=7.11 ; 95 \% C I=1.88-26.92$ ). To minimize hearing and balance impairments bajaj drivers are recommended to work less than 8 hours a day. (Med J Indones 2005; 14: 101-6)
\end{abstract}

Keywords: noise, vibration, hearing, balance impairments, driver

Noise induced hearing loss (NIHL) is a very important problem for industrial workers in both developing and developed countries, especially in countries without hearing conservation programs.

Department of Ear, Nose, and Throat, Faculty of Medicine, University of Indonesia/Dr. Cipto Mangunkusumo Hospital, Jakarta, Indonesia
As a developing country, Indonesia also faces the same problem.

In major cities throughout the world, the general population is increasingly exposed to environmental noise. The tolerated threshold depends on the duration of exposure, frequencies and intensities of noise as well as individual susceptibility. In Indonesia and some countries, noise exposure which has been 
determined safe should not exceed 85 dBA within 8 hours daily or 40 hours weekly. ${ }^{3}$ The health effects of these exposures have to be considered as a more and more important public health problem. In European and American countries, about 35\% of the total population in industry is exposed to noise of more than $85 \mathrm{dBA}^{4}$

Noise and vibration simultaneously could induce hearing and balance impairments, which are rarely diagnosed. Balance impairments gain less attention than hearing problems. Diagnosis of balance impairments is difficult, since the use of posturography to detect balance impairments is relatively new in Indonesia. The advent of this equipment has facilitated the diagnosis of postural balance impairments. It is simple, easy and not time consuming to use, besides being non invasive and reliable in measuring postural sway.

The noisy and vibrating bajaj is a popular means of public transportation in Jakarta. However, it can induce hearing and balance problems for the bajaj drivers. Before an adaptation process is established, the bajaj drivers may have balance impairments, which can be dangerous for the driver themselves and to others, and can be a potential cause of traffic accidents.

The aims of this study were to determine hearing and balance impairments induced by noise and vibration with duration of work and daily working hours by audiometric and posturographic tests, and to determine the thresholds of noise frequencies, intensities, spectrums and acceleration of vibration contributing to the noise.

\section{METHODS}

Sampling was done consecutively among bajaj drivers in the Jakarta area. The study comprised of 2 phases. Firstly, identifying cases of hearing and balance impairments; secondly, identifying the risk factors related to hearing and balance impairments.

Noise and vibration of the bajaj vehicles were measured by a well trained technician, riding around Cipto Mangunkusumo Hospital for about 15 minutes, using an octave band analyzer and vibration meter from Bruël \& Kjær (B\&K). The bajaj drivers were taken to the Neurotological Subdivision of the Ear Nose and Throat (ENT) Department of Cipto Mangunkusumo Hospital. They were interviewed and underwent clinical ENT and neurological examinations, which was carried out from March 2000 until October 2001.

Interviews were conducted using a special questionnaire. Information on demographic characteristics such as age, education, smoking habit, years working as a driver, and the hours per day spent driving the bajaj, were collected. They were further asked if they had experienced sensations of spinning or imbalance (vertigo), or had ringing in their ears (tinnitus). Audiometric testing was done by a nurse using an Interacustic AC 40 audiometer. Posturographic testing was also done by a nurse using an Aima GS - 3000 gravicoder. The tests were performed in a soundproof room at the neurotology clinic, a subdivision of the ENT Department of the Cipto Mangunkusumo Hospital in Jakarta.

All the information was obtained from the drivers prior to the examination. In the audiometric test, the examining nurse instructed the drivers to give a sign whenever they hear a sound. In the posturographic test for balance, the drivers were given four tests. In the first and second tests, they had to stand on a gravicoder without rubber, first with their eyes open and then with their eyes closed. In the third and fourth tests, they stood on a gravicoder with rubber, first with their eyes open and then again with their eyes closed. This last test determined the vestibular function.

Hearing impairment was considered sensorineural if the average hearing level in four frequencies $(500 \mathrm{~Hz}$, $1000 \mathrm{~Hz}, 2000 \mathrm{~Hz}$, and $4000 \mathrm{~Hz}$ ) was more than 25 $\mathrm{dB} .{ }^{3}$ Balance was considered impaired if the results of vestibular function of the fourth posturography test was more then normal (sway velocity $>2.18$, length of sway $>130.68$, envelope area $>6.8$ ). A subject had hearing and balance impairments if he tested positive in both tests, and considered normal if a subject did not have either hearing impairment or balance impairments.

Height and body weight for body mass index were measured using height scale meter and weight scale. A subject was considered undernourished if BMI was $<20$, normal if was BMI 20-25, and obese if BMI was $>25 .{ }^{5}$ Blood pressure was measured on a mercury sphygmomanometer and blood glucose levels determined. Blood pressure was regarded normal if systolic blood pressure was less than $140 \mathrm{mmHg}$ and diastolic blood pressure less than $90 \mathrm{mmHg}{ }^{6}$ 
Maximum peak, maximum level, length of equivalent, minimum level and sound pressure level was measured with a Octave Band Analyser from Bruël \& Kjær (B $\& \mathrm{~K})$ by a trained technician using slow mode scale in $1000,2000,4000,6000$, and 8000 frequencies. Acceleration of vibration was also measured by a trained technician on a vibration meter from Bruël \& Kjær (B \& K). The results were all recorded.

Statistical analysis was done using Stata 6.0 software for logistic regression. ${ }^{7}$ A number of risk factors were examined to determine whether they were potential confounders. A risk factor was considered to be a potential confounder if in the univariate analysis the $P$-value was $<0.25$. It was then considered as a candidate for the multivariate model along with other known risk factors for hearing and balance impairments.

This study was approved by The Committee of The Medical Research Ethics of the Faculty of Medicine, University of Indonesia, Jakarta.

\section{RESULTS}

There were 350 bajaj drivers participating in this study. Of these, $97(27.7 \%)$ subjects did not suffer from either hearing or balance impairment, while 96 $(27.4 \%)$ suffered from hearing and balance problems. The rest or $60(17.2 \%)$ subjects had hearing problems only, and $97(27.7 \%)$ had balance problems only.

The bajaj was found to have a mean intensity level of noise of $91 \mathrm{dBA}$, with minimum intensity of $64 \mathrm{dBA}$ and maximum intensity of $96 \mathrm{dBA}$; the mean acceleration of vibration was $4.2 \mathrm{~m} / \mathrm{sec}^{2}$. The noise and vibration of the bajaj was therefore beyond threshold safety limit based on OSHA and World Health Organization (WHO) criteria.

Table 1 shows that subjects with hearing and balance impairments and normal subjects were similarly distributed with respect to education and smoking habits. Education and smoking habits were not proven to increase the risk of hearing and balance impairments.

Table 1. Some demographic and work load characteristics of subjects and the risk of hearing and balance impairments

\begin{tabular}{|c|c|c|c|c|c|c|c|}
\hline & \multicolumn{2}{|c|}{$\begin{array}{l}\text { Normal } \\
(\mathrm{N}=97)\end{array}$} & \multicolumn{2}{|c|}{$\begin{array}{c}\text { Hearing \& balance } \\
\text { impairments } \\
(\mathrm{N}=96)\end{array}$} & \multirow[t]{2}{*}{$\begin{array}{l}\text { Crude } \\
\text { Odds } \\
\text { ratio }\end{array}$} & \multirow{2}{*}{$\begin{array}{c}95 \% \\
\text { Confidence } \\
\text { intervals }\end{array}$} & \multirow[t]{2}{*}{$\mathrm{p}$} \\
\hline & $\mathrm{n}$ & $\%$ & $\mathrm{n}$ & $\%$ & & & \\
\hline \multicolumn{8}{|l|}{ Age group } \\
\hline $18-40$ years & 76 & 78.3 & 36 & 37.5 & 1.00 & Reference & \\
\hline $41-71$ years & 21 & 21.6 & 60 & 62.5 & 6.03 & $3.19-11.39$ & 0.000 \\
\hline \multicolumn{8}{|l|}{ Education } \\
\hline Elementary school & 68 & 70.1 & 75 & 78.1 & 1.00 & Reference & \\
\hline Junior high school & 22 & 22.7 & 13 & 13.5 & 0.54 & $0.25-1.15$ & 0.108 \\
\hline Senior high school & 7 & 7.2 & 8 & 8.3 & 1.03 & $0.36-3.01$ & 0.948 \\
\hline \multicolumn{8}{|l|}{ Smoking habits } \\
\hline Never smoked & 6 & 6.2 & 13 & 13.5 & 1.00 & Reference & \\
\hline Light smoker & 48 & 49.5 & 36 & 37.5 & 0.35 & $0.12-0.99$ & 0.050 \\
\hline Moderate smoker & 33 & 34.0 & 39 & 40.6 & 0.55 & $0.19-1.59$ & 0.268 \\
\hline Heavy smoker & 5 & 5.1 & 6 & 6.2 & 0.55 & $0.12-2.56$ & 0.449 \\
\hline Ex smoker & 5 & 5.1 & 2 & 2.0 & 0.18 & $0.03-1.24$ & 0.082 \\
\hline \multicolumn{8}{|l|}{ Duration of work } \\
\hline 1.0 - 5.0 years & 46 & 47.4 & 14 & 14.6 & 1.00 & Reference & \\
\hline $5.1-9.0$ years & 14 & 14.4 & 9 & 9.4 & 2.11 & $0.75-5.91$ & 0.154 \\
\hline $9.1-15.0$ years & 24 & 24.7 & 29 & 30.2 & 3.97 & $1.77-8.89$ & 0.001 \\
\hline $15.1-20.0$ years & 8 & 8.2 & 18 & 18.7 & 7.39 & $2.65-20.61$ & 0.000 \\
\hline $20.1-33.0$ years & 5 & 5.1 & 26 & 27.0 & 17.09 & $5.52-52.82$ & 0.000 \\
\hline \multicolumn{8}{|l|}{ Working hours per day } \\
\hline $1-8$ hours & 56 & 57.7 & 8 & 39.6 & 1.00 & Reference & \\
\hline $9-16$ hours & 41 & 42.3 & 58 & 60.4 & 2.08 & $1.17-3.70$ & 0.012 \\
\hline
\end{tabular}


Table 2 shows that subjects with hearing and balance impairments and normal subjects were similarly distributed with respect to nutrition, hemoglobin, blood glucose, blood pressure, and complaints of vertigo and tinnitus. On analysis, these factors were not proven to increase the risk of hearing and balance impairments.

In the final model (Table 3), a relationship was found between age, the amount of daily working hours, the total length of years working as a driver and the risk of hearing and balance impairments. Drivers aged 41 years or more had a four-fold increased risk of developing hearing and balance impairments compared to those aged less than 40 years. Comparing the amount of daily working hours, those working for 9 hours or more a day had a 2.3 -fold increased risk of developing hearing and balance impairments than those who working less than 9 hours a day. Drivers who had been working for 5 years had a tendency to develop hearing and balance impairments. Those who had been working for more than 21 years had a sevenfold increased risk of developing hearing and balance impairments compared to those who had been working for $1-5$ years.

Table 2. Some clinical characteristics of subjects and the risk of hearing and balance impairments

\begin{tabular}{|c|c|c|c|c|c|c|c|}
\hline & \multicolumn{2}{|c|}{$\begin{array}{l}\text { Normal } \\
(\mathrm{N}=97)\end{array}$} & \multicolumn{2}{|c|}{$\begin{array}{l}\text { Hearing \& balance } \\
\text { impairments } \\
(\mathrm{N}=96)\end{array}$} & \multirow{2}{*}{$\begin{array}{l}\text { Crude } \\
\text { odds } \\
\text { ratio }\end{array}$} & \multirow{2}{*}{$\begin{array}{c}95 \% \\
\text { Confidence } \\
\text { intervals }\end{array}$} & \multirow[t]{2}{*}{$\mathrm{p}$} \\
\hline & $\mathrm{n}$ & $\%$ & $\mathrm{n}$ & $\%$ & & & \\
\hline \multicolumn{8}{|l|}{ Body mass index } \\
\hline Normal & 47 & 48.4 & 50 & 52.1 & 1.00 & Reference & \\
\hline Under nourished & 25 & 25.8 & 26 & 27.1 & 0.97 & $0.49-1.93$ & 0.948 \\
\hline Obese & 25 & 25.8 & 20 & 20.8 & 0.75 & $0.37-1.53$ & 0.431 \\
\hline \multicolumn{8}{|l|}{ Hemoglobin } \\
\hline $12-16$ & 29 & 29.9 & 28 & 29.2 & 1.00 & Reference & \\
\hline $10-11$ & 58 & 59.8 & 58 & 60.4 & 1.04 & $0.55-1.95$ & 0.914 \\
\hline $8-9$ & 10 & 10.3 & 10 & 10.4 & 1.04 & $0.37-2.87$ & 0.946 \\
\hline \multicolumn{8}{|l|}{ Blood glucose } \\
\hline Less than 90 & 24 & 24.7 & 22 & 22.9 & 1.00 & Reference & \\
\hline $90-199$ & 72 & 74.2 & 73 & 76.0 & 1.11 & $0.57-2.15$ & 0.766 \\
\hline 200 or more & 1 & 1.1 & 1 & 1.1 & 1.09 & $0.64-18.51$ & 0.952 \\
\hline \multicolumn{8}{|c|}{ Systolic blood pressure } \\
\hline $80-139 \mathrm{mmHg}$ & 88 & 90.7 & 74 & 77.1 & 1.00 & Reference & \\
\hline $140-200 \mathrm{mmHg}$ & 9 & 9.3 & 22 & 22.9 & 2.91 & $1.26-6.69$ & 0.012 \\
\hline \multicolumn{8}{|c|}{ Diastolic blood pressure } \\
\hline $40-89 \mathrm{mmHg}$ & 90 & 92.8 & 86 & 89.6 & 1.00 & Reference & \\
\hline 90-130 mmHg & 7 & 7.2 & 10 & 10.4 & 1.50 & $0.54-4.11$ & 0.435 \\
\hline \multicolumn{8}{|l|}{ Vertigo } \\
\hline No vertigo present & 62 & 63.9 & 58 & 60.4 & 1.00 & Reference & \\
\hline Vertigo present & 35 & 36.1 & 38 & 39.6 & 1.16 & $0.65-2.77$ & 0.616 \\
\hline \multicolumn{8}{|l|}{ Tinitus } \\
\hline No tinitus present & 47 & 48.5 & 38 & 39.6 & 1.00 & Reference & \\
\hline Tinitus present & 50 & 51.5 & 58 & 60.4 & 1.43 & $0.81-2.54$ & 0.215 \\
\hline
\end{tabular}


Table 3. The relationship between age group, duration of work and daily working hours and the risk of hearing and balance impairments

\begin{tabular}{|c|c|c|c|c|c|c|c|}
\hline & \multicolumn{2}{|c|}{$\begin{array}{l}\text { Normal } \\
(\mathrm{N}=97)\end{array}$} & \multicolumn{2}{|c|}{$\begin{array}{c}\text { Hearing \& balance } \\
\text { impairments } \\
(\mathrm{N}=96)\end{array}$} & \multirow[t]{2}{*}{$\begin{array}{l}\text { Adjusted } \\
\text { odds ratio }\end{array}$} & \multirow[t]{2}{*}{$\begin{array}{l}95 \% \text { confidence } \\
\text { intervals }\end{array}$} & \multirow[t]{2}{*}{$\mathrm{p}$} \\
\hline & $\mathrm{n}$ & $\%$ & $\mathrm{n}$ & $\%$ & & & \\
\hline \multicolumn{8}{|l|}{ Age group } \\
\hline $18-40$ years & 76 & 78.4 & 36 & 37.5 & 1.00 & Reference & \\
\hline $41-71$ years & 21 & 21.6 & 60 & 62.5 & 3.90 & $1.67-9.10$ & 0.002 \\
\hline \multicolumn{8}{|l|}{ Daily working hours } \\
\hline $1-8$ hours & 56 & 57.7 & 38 & 39.6 & 1.00 & Reference & \\
\hline $9-16$ hours & 41 & 42.3 & 58 & 60.4 & 2.32 & $1.22-4.41$ & 0.010 \\
\hline \multicolumn{8}{|l|}{ Duration of work } \\
\hline $1-5$ years & 46 & 47.4 & 14 & 14.6 & 1.00 & Reference & \\
\hline $5.1-9.0$ years & 14 & 14.4 & 9 & 9.4 & 2.38 & $0.80-7.00$ & 0.116 \\
\hline $9.1-15.0$ years & 24 & 24.7 & 29 & 30.2 & 2.92 & $1.21-7.02$ & 0.017 \\
\hline $15.1-20.0$ years & 8 & 8.3 & 18 & 18.8 & 3.38 & $1.05-10.80$ & 0.040 \\
\hline $21.01-33.0$ years & 5 & 5.2 & 26 & 27.0 & 7.11 & $1.88-26.92$ & 0.004 \\
\hline
\end{tabular}

\section{DISCUSSION}

Several limitations must be considered in the interpretation of our findings. Sampling, for instance, were drawn consecutively and therefore might not be a representative sample for bajaj drivers working in Jakarta. In addition, the drivers had never in their lives been tested for hearing and balance.

The final result showed that older drivers were at an increased risk of developing hearing and balance problems. This might be due to degenerative processes such as presbycusis, which can induce both hearing and balance problems.

Both problems were also influenced by the length of working years and the amount of daily working hours. Those who worked for a longer period of time or have a daily shift of 9 or more hours had an increased risk of developing both problems. Hearing problems were not quickly realized because initially the problems were only in the high-frequency range, whereas problems with balance were more quickly felt.

A previous report from the iron industry in $\mathrm{Jakarta}^{8}$ found $31.6 \%$ of the workers suffered from noise induced hearing loss (NIHL) in the 85-105 dBA range in 9 years of working, while another study in West Java ${ }^{9}$ found $31.8 \%$ of wood industry workers developed NIHL in the $84.9-108.2 \mathrm{dBA}$ intensity range. Shida studied 527 workers divided into 2 groups, group A
(232 workers) were exposed to noise only and group B (295 workers) were exposed to noise and vibration simultaneously. ${ }^{10}$ The results showed that vibration and noise simultaneously increased the risk of hearing loss. In another study, ${ }^{11}$ animals exposed to an explosion of $158 \mathrm{dBA}$ were found to have severe damage in the cochlea and vestibular organ, particularly in crista ampullaris, and changes in the utricles and saccules. Furthermore, another study of 49 workers with an average age of 30 years who were exposed to noise and vibration of a turbine engine for a period of 6 months to 10 years, reported vestibular impairments in caloric testing. ${ }^{12}$

Obesity can mean an excess of lipid in the blood vessels that could disturb blood circulation and decrease blood supply to the inner ears. This study however, could not prove the adverse effects of obesity on hearing and balance, which might be due to an insufficient number of subjects as sample.

In conclusion, the bajaj is a vehicle that produce noise and vibration over the safety threshold limit, with a mean intensity level of $91 \mathrm{dBA}$ and a mean acceleration of vibration of $4.2 \mathrm{~m} / \mathrm{sec}^{2}$ Noise and vibration produced by the bajaj can induce hearing and balance problems. Bajaj drivers aged 40 years or more, with daily working hours of 9 hours or more, and have worked as a driver for 9 years or more were at an increased risk of developing hearing and balance impairments. Therefore, making public the risks of 
vestibular or balance problems induced by noise and vibration will be very important to the bajaj drivers. The related public health authorities will then be more concerned in preventing hearing and balance impairments to these bajaj drivers.

\section{Acknowledgements}

I would like to thank Prof. Hendarto Hendarmin, Dr. Hamdani Zain, and Prof. Bambang Sutrisna for their technical assistances in this study, and Prof. Bastaman Basuki for reviewing the early drafts of this report.

\section{REFERENCES}

1. Davis I, Robert H, Roger P. Noise and hearing impairment. Occup Health. 1994;3:321-5.

2. Borg E, Canlon B, Engstrom B. Noise induced hearing loss. Literature review and experiments in rabbits. Scand Audiology 1995; 24 (Suppl 40):9-46.

3. OSHA standards guidelines recommended by the AAOHNS. Available from: http://facstaff.uww.edu/bradleys/ohc/audiometry/page22.html

4. Henderson D, Hamernik RP. Biologic bases of noise induced hearing loss. Occup Med 1995; 10:513-34.
5. National Institutes of Health. First federal obesity clinical guidelines released. 1998.

Available from: http://www.nhlbi.nih.gov/new/press/oberelst.htm http://www.naaso.org/

6. Ramsay LE, Williams B, Johnston GD, MacGregor GA, Poston L, et al. Guidelines for management of hypertension: Report of the third working party of the British Hypertension Society. J Human Hypertens 1999; 13:569-92.

7. Stata Corp. Stata Statistical Software: Release 6.0.Getting started with Stata for Windows. Texas: Stata Corporation; 1999.

8. Sundari. Noise induced hearing loss in iron industry workers in Jakarta (Hubungan pemajanan bising dengan ambang pendengaran tenaga kerja di Bagian Peleburan dan Pengontrolan Besi Baja PT BD [thesis). Jakarta: Univ Indonesia; 1994.

9. Lusianawaty T. Noise induced hearing loss in wood industry workers in West Java.(Gangguan pendengaran akibat bising pada tenaga kerja di Perusahaan Plywood PT X, Jawa Barat [thesis]. Jakarta: Univ Indonesia; 1998.

10. Shida S. Vibration and Noise Deafness. Hearing International 1993; 2:1717-8.

11. Ylikoski J. Impulse noise induced damage in the vestibular end organs of the guinea pig. A light microscopic study. Acta Otolaryngol 1987;103:415 - 21 .

12. Aanta E, Virolainen E, Karshela V. Permanent Effects of Low Frequency vibration on the vestibular system. Acta Otolaryngol 1977; 83:470-4. 